\title{
ANTILISTERIAL ACTIVE COMPOUND FROM LACTIC ACID BACTERIA PRESENT ON FRESH ICEBERG LETTUCE
}

\author{
B. Ramos, V. Ferreira, T.R.S. Brandão, P. Teixeira and C.L.M. Silva* \\ $\mathrm{CBQF}$ - Centro de Biotecnologia e Química Fina - Laboratório Associado, Escola Superior de Biotecnologia, \\ Universidade Católica Portuguesa/Porto, Rua Arquiteto Lobão Vital, Apartado 2511, $4202-401$ Porto. Portugal
}

(Received: 8 January 2016; accepted: 17 February 2016)

Pediococcus pentosaceus DT016, a bacteriocin producing strain, was isolated from fresh lettuce. A protein with antilisterial activity (bacDT016), between 11 to $17 \mathrm{kDa}$, was identified and characterized as the bioactive substance from the LAB culture. Highest bacteriocin production was noted after $15 \mathrm{~h}$ of growth. Antibacterial activity was affected by some enzymes and detergents, as well as by temperatures equal or above $80{ }^{\circ} \mathrm{C}$. DT016 strain contains an 1110 bp DNA fragment with homology to pediocin AcH/PA-1.

Keywords: P. pentosaceus DT016, lettuce, bacteriocin, antilisterial activity, L. monocytogenes

The demand for fresh and minimally processed vegetables has increased in the last decades (TriAs et al., 2008). These foods may be consumed raw or minimally processed, and therefore can be a vehicle of several pathogens.

Listeria monocytogenes is ubiquitous in the agricultural environment. Its occurrence in ready-to-eat vegetables may be as high as $25 \%$. In fact, vegetables have been implicated in outbreaks of listeriosis, suggesting that lettuce can have a high incidence of $L$. monocytogenes (RAmos et al., 2013, 2014)

Dairy cows and dairy farm environments are reservoirs of this pathogen, where faecal shedding contributes to its environmental dispersal and contamination of milk, dairy products, and meat represents a risk to consumers (HALEY et al., 2015).

Meat raw materials have often been related with outbreaks of human listeriosis. In effect, a study carried out in Italy from 2008 to 2014 detected L. monocytogenes with an occurrence of $4.2 \%$ in raw pork sausages and of $2.4 \%$ in entrails lamb rolls (D'Ostunt et al., 2016).

Seafood, fish and fishery products are considered as the most frequent causes of a number of sporadic listeriosis cases. The contamination of these products with this pathogen is very likely through contaminated waters and environments, during transportation and in fish markets. L. monocytogenes was isolated from raw fish (6.9\%) and from open-air fish market environment (2.5\%) in Iran (JAMALI et al., 2015).

An increasing number of consumers prefer foods prepared without chemical preservatives to guarantee the microbiology safety. A promising alternative to the use of chemical additives is the use of lactic acid bacteria (LAB) and/or their natural metabolites to enhance food safety. Among these metabolites, bacteriocins are a heterogeneous group of peptides and proteins, able to kill or inhibit the growth of other bacteria (JIANG et al., 2012; JANG et al., 2014). Research on bioactive substances from $L A B$ is important for their potential applications

\footnotetext{
* To whom correspondence should be addressed. Phone: +351 22 5580058; e-mail: clsilva@porto.ucp.pt
} 
in the food industry and public health contribution (O'BRYAN et al., 2015). Bacteriocinogenic $\mathrm{LAB}$, originally isolated from vegetables, are probably the best candidates. Their antibacterial compounds may be used as a weapon to improve the safety of these products, while answering the need for effective biopreservation techniques (WEI et al., 2006).

In this study, the antimicrobial activity of a LAB strain previously isolated from Iceberg lettuce was investigated.

\section{Materials and methods}

\subsection{Antibacterial activity of lactic acid bacteria isolate}

A lactic acid bacterium (DT016) isolated from Iceberg lettuce with activity against $L$. monocytogenes, L. innocua, and E. faecalis was cultured in MRS broth (Lab M) and the antimicrobial activity and its nature were assessed according to ToMé and co-workers (2006). L. innocua 2030c, L. monocytogenes 1334 (1/2c), and L. monocytogenes 1336 (1/2b) were used as target organisms; Pediococcus acidilactici HA-6111-2, a pediocin PA-1 producer (AlBANO et al., 2007) with activity against L. monocytogenes, was used as control.

\subsection{Identification of bacteriocin-producing strain}

Identification of the bacteriocin-producing strain was performed by PCR amplification of 16S rRNA gene as described by PINTO and co-workers (2009).

\subsection{Bacteriocin production}

An overnight culture of $P$. pentosaceus DT016 was inoculated in MRS broth $(1 \% \mathrm{v} / \mathrm{v})$ and incubated at $37{ }^{\circ} \mathrm{C}$, without shaking. Changes in $\mathrm{pH}$ and optical density $(600 \mathrm{~nm})$ were

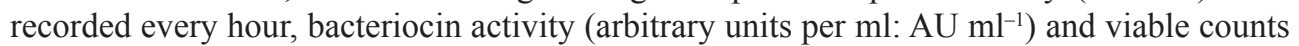
were calculated every 3 h, according to VAN REENEN and co-workers (1998). All experiments were made in triplicate and each sample was measured in duplicate.

\subsection{Bacteriocin molecular weight}

P. pentosaceus DT016 was grown in MRS broth for $18 \mathrm{~h}$ at $37{ }^{\circ} \mathrm{C}$. The bacteriocin was precipitated from the cell-free supernatants (ABRAMS et al., 2011) and proteins were separated by tricine-SDS-PAGE (SCHAGGER \& VON JAGOw, 1987). The gels were fixed and one half stained with Coomassie Brilliant Blue. The position of the active bacteriocin was determined by overlaying the other half of the gel (not stained and pre-washed with sterile distilled water) with cells of $L$. monocytogenes $1336\left(10^{6} \mathrm{CFU} \mathrm{ml}^{-1}\right)$, embedded in TSBYE agar $(0.7 \%$ w/v). Incubation was at $37^{\circ} \mathrm{C}$ for $24 \mathrm{~h}$.

\subsection{Bacteriocin stability}

Cells from an overnight culture of $P$. pentosaceus DT016 were harvested $(8000 \times g, 10 \mathrm{~min}$, $4{ }^{\circ} \mathrm{C}$ ). The antibacterial activity of the cell-free supernatant was studied, as described by ABRAMS and co-workers (2011), after addition of the enzymes proteinase K, pronase, papain, pepsin, and trypsin (Boehringer Mannheim GmbH, Mannheim, Germany), $\alpha$-amylase and catalase (Sigma-Aldrich), and detergents sodium dodecyl sulphate, Tween 20, Tween 80, 
Triton X-114, Triton X-100, ox bile, EDTA urea, and $\mathrm{NaCl}$. The effect of $\mathrm{pH}$ and temperature were also investigated (ABRAMs et al., 2011). All tests were made in triplicate.

\subsection{Cell lysis and adsorption studies}

Cell lysis and adsorption of bacteriocin to producer cells was studied as described by ABRAMS and co-workers (2011). All experiments were made in triplicate and each sample was measured in duplicate.

\subsection{Genes encoding bacteriocin production}

Genes encoding bacteriocin production were identified as described by AlBANO and coworkers (2007). P. acidilactici HA-6111-2 was the positive control strain (Albano et al., 2007). Amplified DNA was purified using the NZY Gelpure kit (NZYTech, Genes and Enzymes), and sequenced by MACROGEN. On-line similarity searches were performed with the BLAST program in GENBANK (2013).

\subsection{Data analysis}

A one-way ANOVA was used to assess the influence of the bacteriocin DT016 addition to the Listeria cultures growth. Multiple comparisons on mean values Listeria enumerations were evaluated by Tukey's post-hoc test using SPSS statistics 22 (IBM, New York, USA). The level of significance for all tests was 0.05 .

\section{Results and discussion}

\subsection{Identification of bacteriocin-producing $L A B$ strain and bacteriocin production/activity}

Growth of the target strains was inhibited by the cell-free supernatant of isolate DT016 and this was associated with an inhibitory compound of proteinaceous nature. Isolate DT016 was identified as Pediococcus pentosaceus.

P. pentosaceus DT016 produces a bacteriocin (bacDT016) during exponential growth (Fig. 1). Low levels of bacDT016 activity against Listeria population were recorded from 6 $\mathrm{h}$ after inoculation, indicating that the peptides are primary metabolites. The highest level of bacteriocin activity was recorded after $15 \mathrm{~h}$ of growth. The activity stabilized for the next $3 \mathrm{~h}$ and then decreased over the following $6 \mathrm{~h}$ (Fig. 1). This decrease was probably due to the effect of extracellular proteases, adsorption to cell surfaces, and to feedback regulation (ANASTASiadou et al., 2008). 
A

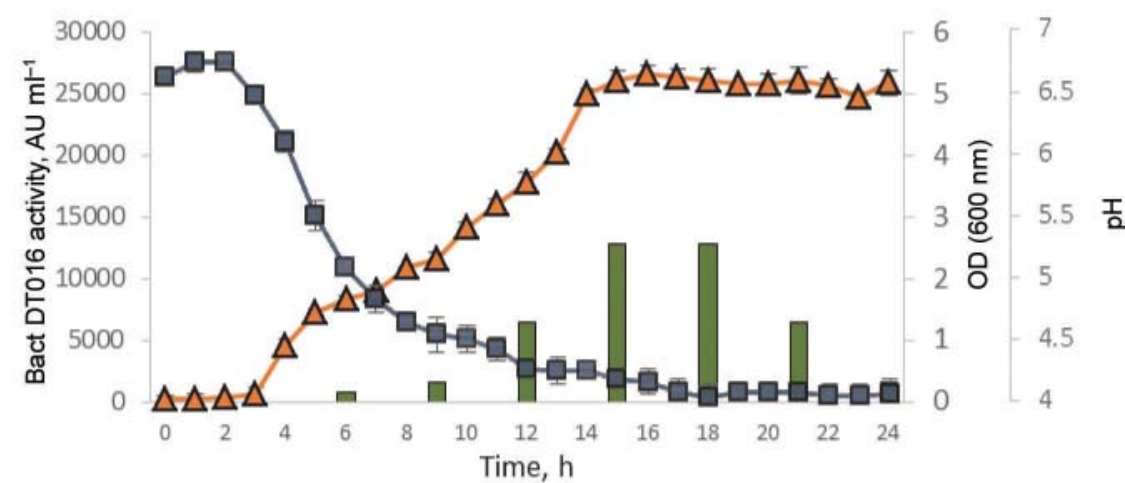

B
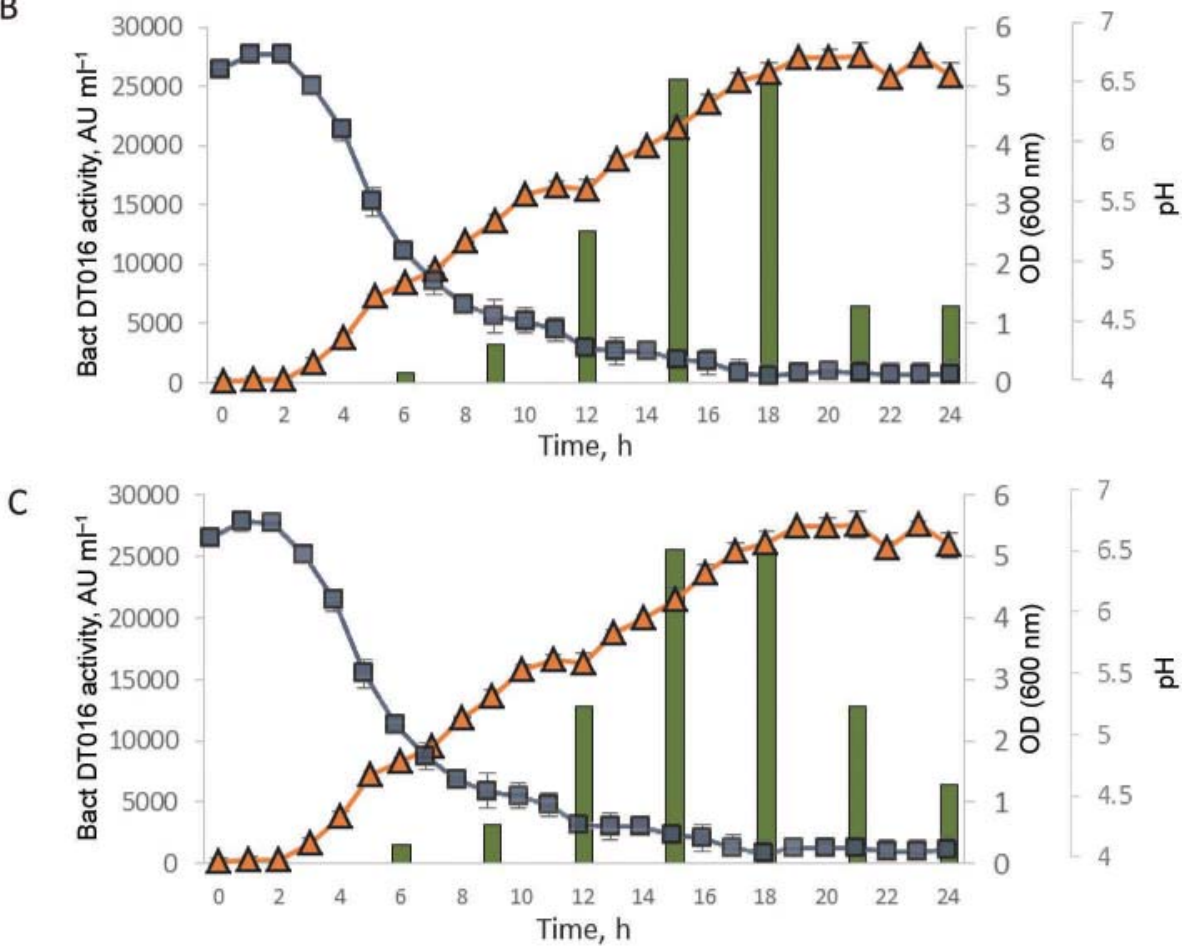

Fig. 1. Production of bacteriocin DT016 in MRS broth $(\mathrm{pH} 6.4)$ at $37^{\circ} \mathrm{C}$. Antimicrobial activity is presented as $\mathrm{AU} \mathrm{ml}^{-1}$ (bars). The target strains are for A: Listeria inoccua 2030c; B: L. monocytogenes 1334; C: L. monocytogenes 1336. Changes in optical density $(\mathbf{\Delta})$ and $\mathrm{pH}(\square)$ are indicated. Error bars show standard deviation

\subsection{Bacteriocin molecular weight}

From the association between the zone of growth inhibition and the peptide band position, the active protein was determined (Fig. 2). BacDT016 is between 11 and $17 \mathrm{kDa}$ in size; this is higher than most bacteriocins previously described for Pediococcus spp. However, pediocin from P. acidilactici PAC1.0 has a molecular weight around $16.5 \mathrm{kDa}$ (PAPAGiann \& Anastasiadou, 2009). 


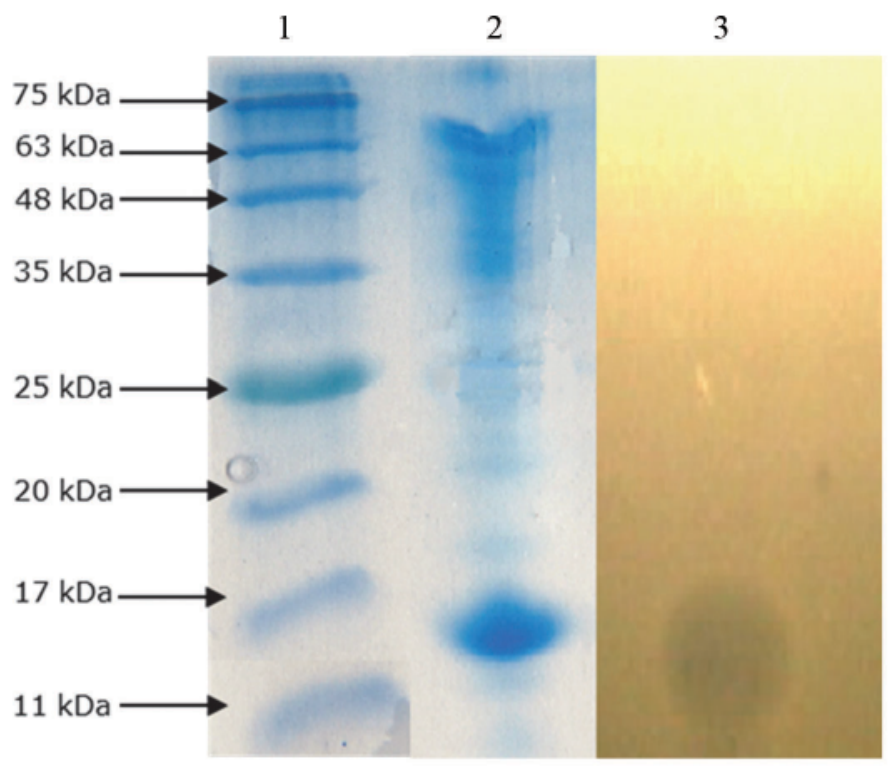

Fig. 2. Tricine-SDS-PAGE of bacteriocin DT016. Lane 1: molecular mass marker; lane 2: peptide band stained with Coomassie Blue R250; lane 3: zone of growth inhibition, corresponding to the position of the peptide band in lane 2

Based on the strong antilisterial activity, it is likely that bacDT016 is a class IIa bacteriocin (MARTINEZ et al., 2013).

\subsection{Bacteriocin stability}

Treatment of bacDT016 with proteinase $\mathrm{K}$, pronase and trypsin $\left(0.1\right.$ and $\left.1.0 \mathrm{mg} \mathrm{ml}^{-1}\right)$ resulted in complete loss of antibacterial activity (Table 1$)$. The addition of papain $\left(0.1 \mathrm{mg} \mathrm{ml}^{-1}\right.$ and 1 $\left.\mathrm{mg} \mathrm{ml}^{-1}\right)$ and pepsin $\left(1 \mathrm{mg} \mathrm{ml}^{-1}\right)$ reduced the antibacterial activity. Sensitivity was strain dependent.

BacDT016 was resistant to treatment with SDS, Tween 20, Tween 80, ox bile, EDTA, urea, and $\mathrm{NaCl}$. However, the bacteriocin showed sensitivity to Triton X-100 and Triton $\mathrm{X}$-114. The bacteriocin remained stable for $\mathrm{pH}$ values ranging from 4.0 to 8.0 (Table 1). Antimicrobial activity was strongly reduced at $\mathrm{pH}$ values of 2.0 and above 8.0. Similar results have been reported for pediocin AcH/PA-1 (AlBANO et al., 2007).

Temperatures between 4 and $60{ }^{\circ} \mathrm{C}$ had almost no effect in the bacteriocin activity. Antibacterial activity decreased gradually at temperatures above $60{ }^{\circ} \mathrm{C}$. Remarkably, antibacterial activity could still be recorded after $15 \mathrm{~min}$ at $121^{\circ} \mathrm{C}$. Similar results have been reported for other bacteriocins produced by Pediococcus spp. (Todorov \& Dicks, 2009). 
Table 1. Effect of treatments on the antibacterial activity of bacteriocin DT016

\begin{tabular}{|c|c|c|c|c|}
\hline \multicolumn{5}{|c|}{ Bacteriocin DT016 } \\
\hline & \multicolumn{4}{|c|}{ Pathogen } \\
\hline & & $\begin{array}{c}\text { L. innocua } \\
2030 \mathrm{c} \\
\%\end{array}$ & $\begin{array}{c}\text { L. monocytogenes } \\
1334(1 / 2 \mathrm{c}) \\
\%\end{array}$ & $\begin{array}{c}\text { L. monocytogenes } \\
1336(1 / 2 \mathrm{~b}) \\
\%\end{array}$ \\
\hline \multirow{9}{*}{ Enzymes } & Proteinase $\mathrm{K} 1.0$ and $0.1 \mathrm{mg} \mathrm{ml}^{-1}$ & 100 & 100 & 100 \\
\hline & Pronase 1.0 and $0.1 \mathrm{mg} \mathrm{ml}^{-1}$ & 100 & 100 & 100 \\
\hline & Papain $0.1 \mathrm{mg} \mathrm{ml}^{-1}$ & 50 & 50 & 50 \\
\hline & Papain $1.0 \mathrm{mg} \mathrm{ml}^{-1}$ & 75 & 87.5 & 87.5 \\
\hline & Pepsin $0.1 \mathrm{mg} \mathrm{ml}^{-1}$ & 50 & 0 & 0 \\
\hline & Pepsin $1.0 \mathrm{mg} \mathrm{ml}^{-1}$ & 75 & 87.5 & 87.5 \\
\hline & Trypsin 1.0 and $0.1 \mathrm{mg} \mathrm{ml}^{-1}$ & 100 & 100 & 100 \\
\hline & $\alpha$-Amylase 1.0 and $0.1 \mathrm{mg} \mathrm{ml}^{-1}$ & 0 & 0 & 0 \\
\hline & Catalase 1.0 and $0.1 \mathrm{mg} \mathrm{ml}^{-1}$ & 0 & 0 & 0 \\
\hline \multirow{9}{*}{ Detergents } & SDS $0.01 \mathrm{~g} \mathrm{ml}^{-1}$ & 0 & 0 & 0 \\
\hline & Tween $200.01 \mathrm{~g} \mathrm{ml}^{-1}$ & 0 & 0 & 0 \\
\hline & Tween $800.01 \mathrm{~g} \mathrm{ml}^{-1}$ & 0 & 0 & 0 \\
\hline & Triton X-114 $0.01 \mathrm{~g} \mathrm{ml}^{-1}$ & 50 & 50 & 50 \\
\hline & Triton X-100 $0.01 \mathrm{~g} \mathrm{ml}^{-1}$ & 50 & 50 & 50 \\
\hline & Ox bile $0.01 \mathrm{~g} \mathrm{ml}^{-1}$ & 0 & 0 & 0 \\
\hline & EDTA $0.1,2.0$ and $5.0 \mathrm{mM}$ & 0 & 0 & 0 \\
\hline & Urea $0.01 \mathrm{~g} \mathrm{ml}^{-1}$ & 0 & 0 & 0 \\
\hline & $\mathrm{NaCl} 0.01 \mathrm{~g} \mathrm{ml}^{-1}$ & 0 & 0 & 0 \\
\hline \multirow{6}{*}{$\mathrm{pH}$} & 2.0 & 50 & 50 & 50 \\
\hline & 4.0 & 0 & 0 & 0 \\
\hline & 6.0 & 0 & 0 & 0 \\
\hline & 8.0 & 0 & 0 & 0 \\
\hline & 10.0 & 75 & 50 & 75 \\
\hline & 12.0 & 75 & 75 & 75 \\
\hline \multirow{8}{*}{$\begin{array}{l}\text { Tempera- } \\
\text { ture }\end{array}$} & $4^{\circ} \mathrm{C}$ & 0 & 0 & 0 \\
\hline & $25^{\circ} \mathrm{C}$ & 0 & 0 & 0 \\
\hline & $30^{\circ} \mathrm{C}$ & 0 & 0 & 0 \\
\hline & $37^{\circ} \mathrm{C}$ & 0 & 0 & 0 \\
\hline & $60^{\circ} \mathrm{C}$ & 0 & 0 & 0 \\
\hline & $80^{\circ} \mathrm{C}$ & 25 & 25 & 25 \\
\hline & $100^{\circ} \mathrm{C}$ & 50 & 50 & 50 \\
\hline & $121^{\circ} \mathrm{C}$ & 87.5 & 75 & 75 \\
\hline
\end{tabular}




\subsection{Cell lysis and adsorption studies}

Addition of bacDT016 to early-log cultures of the target strains (OD600 nm $\approx 0.1$ ) decreased the growth for $10 \mathrm{~h}(\mathrm{P}>0.05)$ (Fig. 3)

A

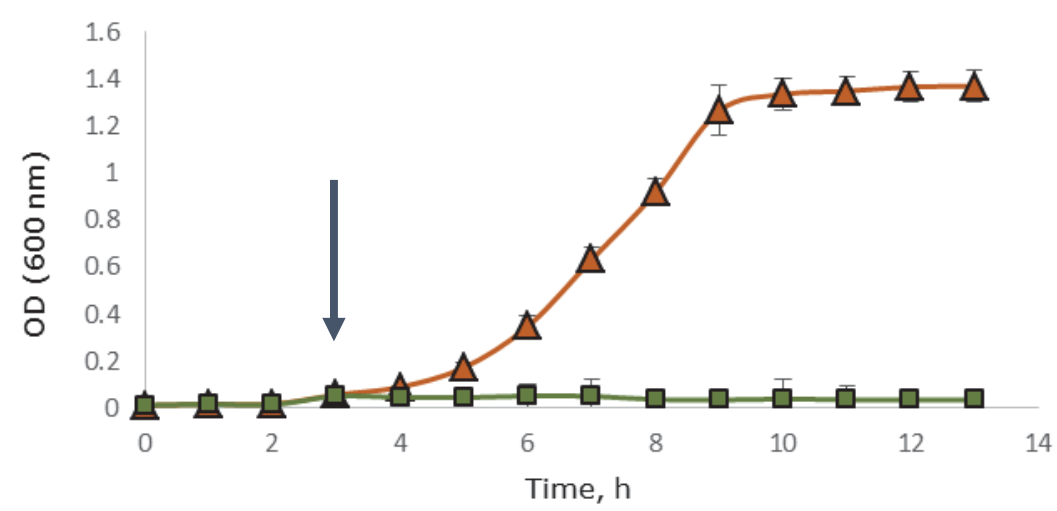

B

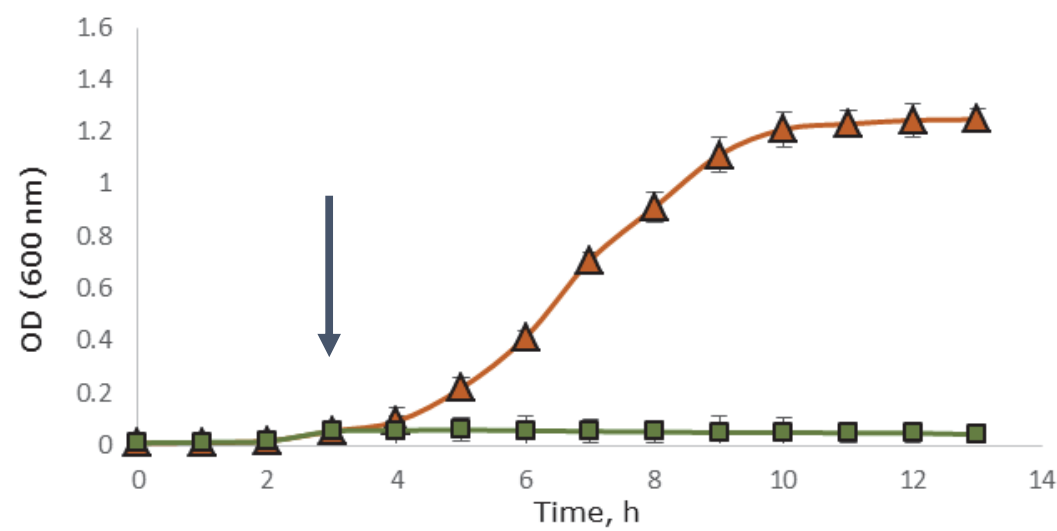

C

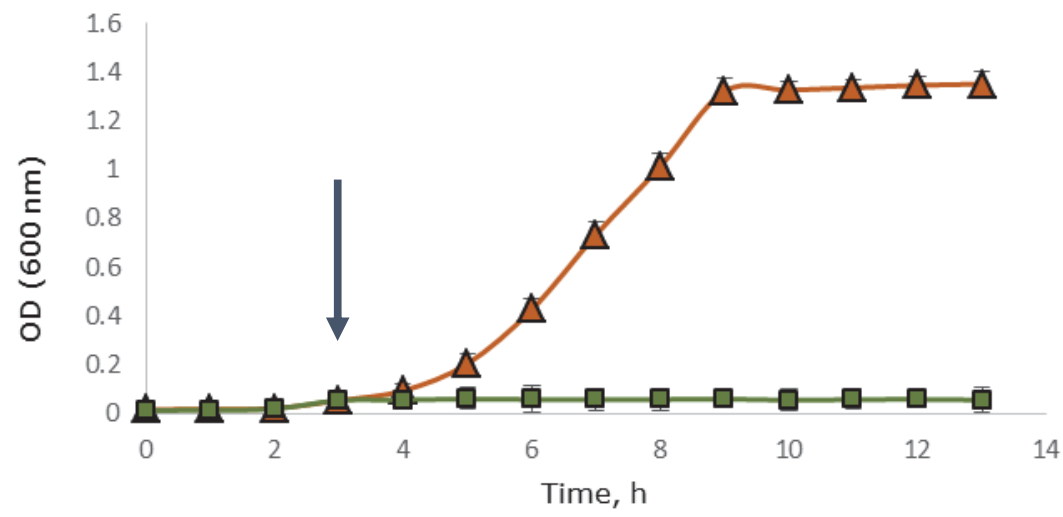

Fig. 3. Effect of bacteriocin DT016 on the growth ( $\square$ ) of A: L. innocua 2030c; B: L. monocytogenes 1334, C: L. monocytogenes 1336 . The symbol $(\Delta)$ represents the growth without added bacteriocin (controls). Arrows indicate the point at which the bacteriocin was added $(3 \mathrm{~h})$. Error bars show standard deviation 
RAMOS et al.: ANTILISTERIAL ACTIVE COMPOUND FROM LACTIC ACID BACTERIA

423

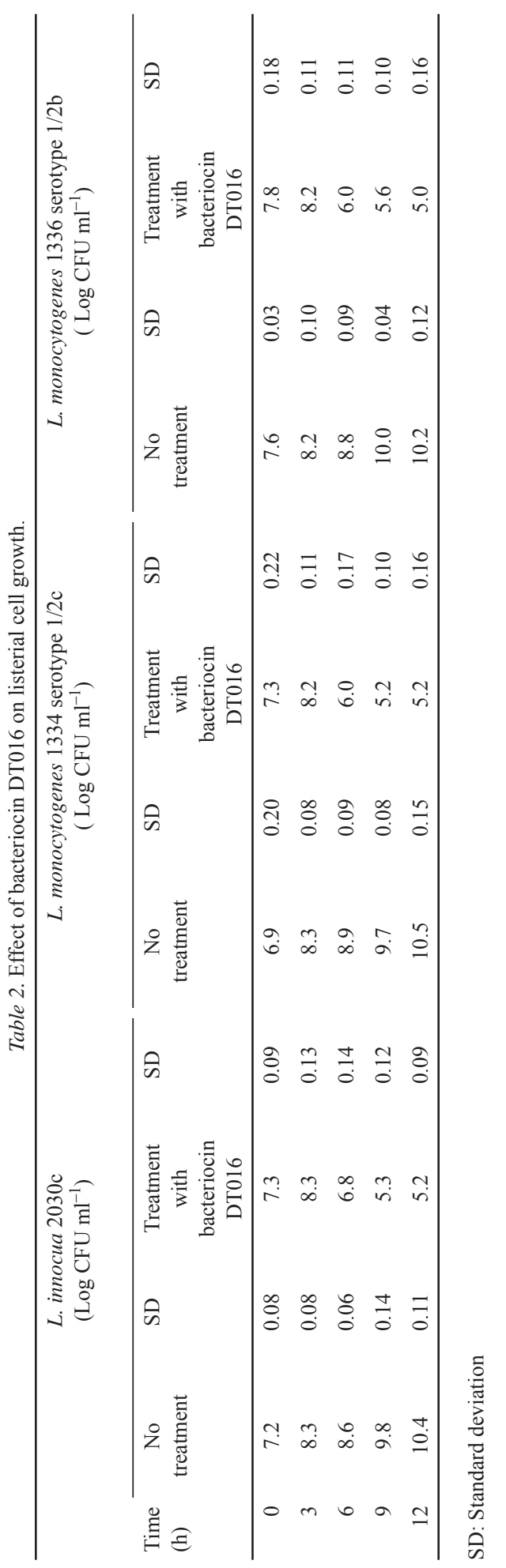

Act Alimentaria 45, 2016 
The bacteriocin demonstrated bactericidal activity against Listeria cells. In the untreated samples (control) Listeria cells increased along the $13 \mathrm{~h}$ of the study, reaching the stationary phase. At $12 \mathrm{~h}$ the maximum loads of L. innocua 2030c, L. monocytogenes strains 1334 and 1336 were $10.4,10.2$, and $10.2 \log \mathrm{CFU} \mathrm{m}{ }^{-1}$, respectively. After $3 \mathrm{~h}$ of the bacteriocin application, there was a decrease in Listeria cells of about 1.5, 2.2, and 2.2 to L. innocua 2030c, L. monocytogenes 1334, and L. monocytogenes 1336, respectively (Table 2). At the end of the experiment, a difference on Listeria cells growth of $\approx 5 \log \mathrm{CFU} \mathrm{ml} \mathrm{m}^{-1}(\mathrm{P}<0.05)$ between the samples with no bacteriocin and with bacteriocin added was observed (Table 2 ).

No bacteriocin activity was detected after treatment of $P$. pentosaceus DT016 with 100 $\mathrm{mM} \mathrm{NaCl} \mathrm{pH} 2.0$ (data not shown), suggesting that the bacteriocins did not adhere to the surface of the producer cells. Similar results were reported for other bacteriocins (IVANOVA et al., 2000; Todorov \& Dicks, 2005; Albano et al., 2007).

\subsection{Genes encoding bacteriocin production}

P. pentosaceus DT016 has an 1110 bp DNA fragment with homology to pediocin AcH/PA-1 [Genbank accession number NG_035882.1 (MilLER et al., 2005)]. Bacteriocin DT016 is thus considered similar to pediocin $\mathrm{AcH}$.

\subsection{Biopreservation potential}

The LAB culture, $P$. pentosaceus DT016, described in this study shows promising potential as a protective culture to inhibit and reduce $L$. monocytogenes proliferation in vegetables. In fact, the effective inhibition of $L$. monocytogenes by the application of $P$. pentosaceus strains as starter culture to various foods has been demonstrated (HuANG et al., 2009; KINGCHA et al., 2012; JANG et al., 2015). On the other hand, the bacteriocin produced is homologous to pediocin $\mathrm{AcH}$, which have been extensively studied and is considered a good biopreservative agent (Miller et al., 2005; Nieto-LozAno et al., 2010).

\section{Conclusions}

Bacteriocin bacDT016 produced by a strain of P. pentosaceus originally isolated from Iceberg lettuce exhibits activity against $L$. monocytogenes and $L$. innocua. Antilisterial activity was traced to a heat-resistant 11 to $17 \mathrm{kDa}$ protein similar to pediocin $\mathrm{AcH}$. In addition, bactDT016 is stable in a wide range of $\mathrm{pH}$ and maintains the antilisterial activity at refrigeration temperature $\left(4^{\circ} \mathrm{C}\right)$.

In conclusion, $P$. pentosaceus DT016 has the potential to be used as a bioprotective culture in minimally processed vegetables and fruit, and the antibacterial compound produced may improve the safety and shelf-life of these products, while answering the need for effective biopreservation techniques.

This work was supported by National Funds from FCT - Fundação para a Ciência e a Tecnologia through project PEst-OE/EQB/LA0016/2013.

Financial support for Ramos B., Ferreira, V. and Brandẽo T.R.S. was provided by FCT and Fundo Social Europeu (FSE) through fellowships SFRH/BD/42169/2007, SFRH/BPD/72617/2010 and SFRH/BPD/41419/2007, respectively.

Collaboration of Diana Silva and Tatiana Esteves in the experimental procedures is gratefully acknowledged. 


\section{References}

Abrams, D., Barbosa, J., Albano, H., Silva, J., Gibbs, P.A. \& Teixeira, P. (2011): Characterization of bacPPK34 a bacteriocin produced by Pediococcus pentosaceus strain K34 isolated from "Alheira". Food Control, 22, $940-946$.

Albano, H., Todorov, S.D., van Reenen, C.A., Hogg, T., Dicks, L.M.T. \& Teixeira, P. (2007): Characterization of two bacteriocins produced by Pediococcus acidilactici isolated from "Alheira", a fermented sausage traditionally produced in Portugal. Int. J. Food Microbiol., 116, 239-247.

Anastasiadou, S., Papagianni, M., Filiousis, G., Ambrosiadis, I. \& Koidis, P. (2008): Pediocin SA-1, an antimicrobial peptide from Pediococcus acidilactici NRRL B5627: Production conditions, purification and characterization. Bioresource Technol., 99(13), 5384-5390.

D’Ostuni, V., Tristezza, M., De Giorgi, M.G., Rampino, P., Grieco, F. \& Perrotta, C. (2016): Occurrence of Listeria monocytogenes and Salmonella spp. in meat processed products from industrial plants in Southern Italy. Food Control, 62, 104-109.

GenBanK (2013): http://www.ncbi.nlm.nih.gov (last accessed in January 2015).

Haley, B.J., Sonnier, J., Schukken, Y.H., Karns, J.S. \& VAn Kessel, J.A. (2015): Diversity of Listeria monocytogenes within a U.S. dairy herd, 2004-2010. Foodborne Pathog. Dis., 12, 844-850.

Huang, Y., Luo, Y., Zhai, Z., Zhang, H., Yang, C., Tian, H., Li, Z., Feng, J., Liu, H. \& HaO, Y. (2009): Characterization and application of an anti-Listeria bacteriocin produced by Pediococcus pentosaceus 05-10 isolated from Sichuan Pickle, a traditionally fermented vegetable product from China. Food Control, 20, 1030-1035.

Ivanova, I., Kabadjova, P., Pantev, A., Danova, S. \& Dousset, X. (2000): Detection, purification and partial characterization of a novel bacteriocin substance produced by Lactococcus lactis susp. lactis B14 isolated from boza - Bulgarian traditional cereal beverage. Biocatalysis 2000, Fundamentals and Applications, Moskow, Russia, 10-15 June 2000, Vest. Mosk. U. Khim. +, 41, 47-53.

Jamali, H., Paydar, M., Ismail, S., Looi, C.Y., Wong, W.F., Radmehr, B. \& Abedini, A. (2015): Prevalence, antimicrobial susceptibility and virulotyping of Listeria species and Listeria monocytogenes isolated from open-air fish markets. BMC Microbiol., 15(1), 1-7.

JANG, S., LeE, D., JANG, I.S., ChoI, H.S. \& SuH, H.J. (2015): The culture of Pediococcus pentosaceus T1 inhibits Listeria proliferation in salmon fillets and controls maturation of kimchi. Food Technol. Biotech., 53, $29-37$.

JANG, S., LeE, J., Jung, U., Chol, H.-S. \& SuH, H.J. (2014): Identification of an anti-listerial domain from Pediococcus pentosaceus T1 derived from Kimchi, a traditional fermented vegetable. Food Control, 43, 42-48.

JiAng, J., Shi, B., Zhu, D., CAI, Q., Chen, Y., Li, J., QI, K. \& ZhANG, M. (2012): Characterization of a novel bacteriocin produced by Lactobacillus sakei LSJ618 isolated from traditional Chinese fermented radish. Food Control, 23, 338-344.

Kingcha, Y., Tosukhowong, A., Zendo, T., Roytrakul, S., Luxananil, P., Chareonpornsook, K., Valyasevi, R., Sonomoto, K. \& Visessanguan, W. (2012): Anti-listeria activity of Pediococcus pentosaceus BCC 3772 and application as starter culture for Nham, a traditional fermented pork sausage. Food Control, 25, 190-196.

Martinez, R.C.R., Wachsman, M., Torres, N.I., LeBlanc, J.G., Todorov, S.D. \& Franco, B.D.G.D.M. (2013): Biochemical, antimicrobial and molecular characterization of a noncytotoxic bacteriocin produced by Lactobacillus plantarum ST71KS. Food Microbiol., 34, 376-381.

Miller, K.W., Ray, P., Steinmetz, T., Hanekamp, T. \& Ray, B. (2005): Gene organization and sequences of pediocin AcH/PA-1 production operons in Pediococcus and Lactobacillus plasmids. Lett. Appl. Microbiol., 40, 56-62.

Nieto-Lozano, J.C., Reguera-Useros, J.I., Peláez-Martínez, M.D.C., Sacristán-Pérez-Minayo, G., GutiérrezFernández, Á.J. \& DE la Torre, A H. (2010): The effect of the pediocin PA-1 produced by Pediococcus acidilactici against Listeria monocytogenes and Clostridium perfringens in Spanish dry-fermented sausages and frankfurters. Food Control, 21, 679-685.

O’Bryan, C.A., Crandall, P.G., Ricke, S.C. \& Ndahetuye, J.B. (2015): 7 - Lactic acid bacteria (LAB) as antimicrobials in food products: Analytical methods and applications. -in: TAYLOR, T.M. (Ed.), Handbook of natural antimicrobials for food safety and quality. Woodhead Publishing, Oxford, pp. 137-151.

Papagianni, M. \& Anastasiadou, S. (2009): Pediocins: The bacteriocins of Pediococci. Sources, production, properties and applications. Microb. Cell Fact., 8, 3.

Pinto, A.L., Fernandes, M., Pinto, C., Albano, H., Castilho, F., Teixeira, P. \& Gibbs, P.A. (2009): Characterization of anti-Listeria bacteriocins isolated from shellfish: Potential antimicrobials to control non-fermented seafood. Int. J. Food Microbiol., 129, 50-58.

Ramos, B., Brandão, T.R.S., Teixeira, P. \& Silva, C.L.M. (2014): Balsamic vinegar from Modena: An easy and effective approach to reduce Listeria monocytogenes from lettuce. Food Control, 42, 38-42. 
Ramos, B., Miller, F.A., Brandão, T.R.S., Teixeira, P. \& Silva, C.L.M. (2013): Fresh fruits and vegetables - An overview on applied methodologies to improve its quality and safety. Innov. Food Sci. Emerg., 20, 1-15.

Schagger, H. \& von JAGOw, G. (1987): Tricine-sodium dodecyl sulfate-polyacrylamide gel electrophoresis for the separation of proteins in the range from 1 to $100 \mathrm{kDa}$. Anal. Biochem., 166, 368-379.

Todorov, S.D. \& Dicks, L.M.T. (2005): Pediocin ST18, an anti-listerial bacteriocin produced by Pediococcus pentosaceus ST18 isolated from boza, a traditional cereal beverage from Bulgaria. Process Biochem., 40, $365-370$.

Todorov, S.D. \& Dicks, L.M.T. (2009): Bacteriocin production by Pediococcus pentosaceus isolated from marula (Scerocarya birrea). Int. J. Food Microbiol., 132(2-3), 117-126.

Tomé, E., Teixeira, P. \& GibBs, P.A. (2006): Anti-listerial inhibitory lactic acid bacteria isolated from commercial cold smoked salmon. Food Microbiol., 23, 399-405.

Trias, R., Bañeras, L., Badosa, E. \& Montesinos, E. (2008): Bioprotection of Golden Delicious apples and Iceberg lettuce against foodborne bacterial pathogens by lactic acid bacteria. Int. J. Food Microbiol., 123(1-2), 50-60.

van Reenen, C.A., Dicks, L.M. \& Chikindas, M.L. (1998): Isolation, purification and partial characterization of plantaricin 423, a bacteriocin produced by Lactobacillus plantarum. J. Appl. Microbiol., 84, 1131-1137.

Wei, H., Wolf, G. \& Hammes, W.P. (2006): Indigenous microorganisms from iceberg lettuce with adherence and antagonistic potential for use as protective culture. Innov. Food Sci. Emerg., 7(4), 294-301. 